\title{
PASAR, MASJID, DAN MADRASAH: PENDIDIKAN ISLAM DI MINORITAS MUSLIM
}

\author{
${ }^{1}$ Ismail Suardi Wekke, ${ }^{2}$ Hudi Asrori, ${ }^{3}$ Randi Wahyu Eko S, ${ }^{4}$ Salvia Salvia, ${ }^{5}$ Yeni \\ Wulandari, ${ }^{6}$ Firdaus Firdaus \\ ${ }^{1}$ Sekolah Tinggi Agama Islam Negeri (STAIN) Sorong \\ ${ }^{2}$ Sekolah Tinggi Agama Islam Negeri (STAIN) Sorong \\ ${ }^{3}$ Sekolah Tinggi Agama Islam Negeri (STAIN) Sorong \\ ${ }^{4}$ Sekolah Tinggi Agama Islam Negeri (STAIN) Sorong \\ ${ }^{5}$ Sekolah Tinggi Agama Islam Negeri (STAIN) Sorong \\ ${ }^{6}$ Universitas Indonesia
}

Email: ismail@stain-sorong.ac.id, ashudi168@gmail.com, rendiwahyuekos@gmail.com, salviasalvia070@gmail.com, ywulandari561@gmail.com, fdaus5577@gmail.com

\begin{abstract}
Abstrak
Penelitian ini bertujuan untuk mengungkapkan bagaimana hubungan mesjid, lembaga sekolah, dan pasar dalam meningkatkan pendidikan di masyarakat. Penelitian ini mengunakan metode Observasi dan wawancara. Wawancara dilakukan dengan Kepala sekolah serta wali murid SMP Quba Kota Sorong. Adapun observasi dilakukan pada lingkungan sekolah, pasar, serta mesjid yang menjadi awal sekolah tersebut dibangun. Adapun hasil dari penelitian ini disimpulkan bahwa di kota Sorong terdapat sebuah pasar dengan nama pasar Central. Pasar tersebut letaknya berdekatan dengan mesjid Quba. Keberadaan mesjid Quba di sekitar pasar Central memiliki peranan yang sangat penting bagi orang-orang yang sedang berniaga di pasar. Pasar dan mesjid tidak dapat dipisahkan keduanya saling membutuhkan dan saling menguntungkan antara satu dengan yang lainnya. Selain pasar dan mesjid, terdapat lembaga pendidikan yang barada di dekat lingkungan pasar tersebut, di kenal dengan nama SMP Quba. Walaupun letaknya berdampingan dengan pasar yang dikenal dengan keramainya setiap hati ini tidak menggurangi ataupun menggangu aktifitas belajar mengajar yang terjadi pada lembaga pendidikan tersebut Dengan melihat dari fungsi sekolah, maka SMP Quba yang berada disekitar pasar dan mesjid merupakan suatu kesatuan realitas kehidupan yang mampu menjadikan masyarakaynya menjadi masyarakat madani.
\end{abstract}

Keyword: Pasar, Masjid, Madrasah

\section{Pendahuluan}

Masyarakat adalah sekelompok manusia yang terjalin erat karena sistem tertentu, tradisi tertentu, konvensi dan hukum tertentu yang sama dan hidup bersama. Hidup bersama tidak berarti sekelompok orang mestihidup berdampingan di satu daerah tertentu, 
memanfaatkan iklim ang sama, dan mengkonsumsikan makanan yang sama. Pepohonan di tanam hidup berdampingan, memanfaatkan iklim yang sama, dan mengkonsumsi makanan yang sama. Begitu pula, kawanan rusa makan rumput bersaa dan kemana-mana bersama. Namun pepohonan maupun kawanan rusa itu tidakhidup bersama atau bermasyarakat.

Kehidupan manusia adalah kehidupan sosial, dalam arti bahwa kehidupan manusia bersifat sosial. Kebutuhan, prestasi kesenangan dan aktifitas manusia semuanya bersifat sosial, karena semuanya itu terjalin erat dengan adat, kebiasaan, dan sistem kerja, pembagian keuntungan, dan pembagian pemenuhan kebutuhan tertentu. Yang membuat sekelompok tertentu orang tetap bersatu adalah pikiran dan kebiasaan tertentu yang dominan. Dengan kata lain, masyarakat adalah kumpulan orang yang, karena desakan kebutuhan dan pengaruh keyakinan, pikiran dan ambisi tertentu, tersatukan dalam kehidupan bersama (Murtadha Nuthahhari, 2002: 267-268).

Manusia sebagai makhluk sosial memerlukan interaksi untuk tetap bertahan dalam kehidupannya. Interaksi tersebut dapat terlihat dari kehidupan yang ada di dalam masyarakat. Sebagai terwujud dalam aktifitas berniaga, beribadah, dan juga dalam hal memperoleh pendidikan. Dalam proses perniagaan, pasar merupakan aktifitas nyata di sekitar kita khususnya di kota Sorong. Pasar utama yang ada di kota Sorong ini lebih dikenal dengan nama Pasar Central. Pasar tersebut terletak di Remu Selatan Papua Barat.

Pasar Central, terdapat juga sebuah mesjid yang bernama mesjid Quba. Mesjid tersebut merupakan tempat ibadah bagi kaum muslimin yang berada disekitar lingkungan pasar. Dilihat dari kondisi geografinya, mesjid ini terletak pada posisi yang strategis. Hal ini dikarenakan banyaknya penjual dan pembeli yang berlalu lalang dalam melakukan proses perniaga di pasar. Selain terlihat dari letak geografinya, sisi startegisnya mesjid ini juga terlihat dari mayoritas penjual dan pembeli yang beragama Islam. Sehingha mesjid Quba tersebut senantiasa di padati oleh jamaah. Bahkan kondisi mesjid sekarang justru banyak di padati pula oleh pedagang-pedagang asongan yang berdagang di sekitar mesjid tersebut. Mulai dari pedagang kue sampai pedagang minyak wangi.

Mesjid berarti tempat untuk bersujud, secara secara terminologis diartikan sebagai tempat beribadah umat Islam. Khususnya dalam menegakan shalat. Mesjid sering disebut 
Baitullah (rumah Allah), yaitu bangunan yang didirikan sebagai sarana menghadap kepada Allah Swt. mesjib berfungsi ebagai tempat untuk melaksanakan ibadah shalat berjamaah. Kalau kita perhatikan, shalat berjamaah adalah salah satu ajaran Islam yang pokok. Ajaran Rasulullah Saw. Tentang shalat berjamaah merupakan perintah ang benar-benar ditetakan kepada kaum muslimin.

Umat islam tidak dapat bisa terlapas dari Mesjid. Hampir dapat dikatakan dimana ada komunitas muslim disitu ada di mesjid. Banyak mesjid didirikan umat Islam baik mesjid umum, mesjid sekolah, mesjid kantor, mesjid kampus maupun yang lainya. Mesjid didirikan untuk memenuhi hajat umat. Khususnya kebutuhan spiritual, guna mendekatkan diri kepada penciptaNya. Tunduk dan patuh mengapdi kepada Allah Swt. mesjid juga sebagai tambahan hati bagi setiap orang yang berada didalamnya.

Mesjid Quba selain digunakan sebagai tempat ibadah, juga digunakan sebagai tempat menuntut ilmu, terbukti dengan didirikannyasekolah Quba di mesjid tersebut yang diberi nama SD Quba, sama dengan nama mesjid tersebut. Mayoritas siswa di SD tersebut adalah masyarakat sekitar pasar atau mesjid itu sendiri. Terbukti dari pendapat masyarakat yang menyekolakan anaknya ke SD Quba yakni dengan beranggapan bahwa sekolah tersebut merupakan sekolah Islam satu-satunya di sekitar pasar. Sekolah Quba tersebut merupakan sekolah yang memfasilitasi warga sekitar pasar dengan sekolah berbasis Islam yang lebih mengedepankan anak didiknya barperilaku yang bartanggaung jawab dan menjunjung tinggi nilai-nilai agama dan budaya. Hal tersebut dapat telihat dari salah satu visi sekolah tersebut.

Pada perkembanganya yayasan tersebut juga mendirikan Sekolah Menegah pertama (SMP) yang ditujukan bagi alimmi SD Quba yang ingin melanjutkan ke jenjeng yang lebih tinggi. Hal ini dibuktikan dengan didirikan sebuah sekolah yang diberi nama dengan SMP Quba. SMP ini didirikan dalam rangka memenuhi kebutuhan masyarakat sekitar akan pendidikan. Untuk mengimbangi persaingan pendidikan pada era teknologi, SMP Quba merumuskan misinya yang mengedepankan perkembangan IMPTEK (ilmu penegtahuan dan teknologi) dengan dilandasi IMTAK (ilmu dan takwa). 
Menurut Mujayyin Arifin, (2010: 58) dalam bukunya yang berjudul Filsafat Pendidikan Islam, berpendapat bahwa perkembangan manusia itu berlangsung atas pengaruh dari faktor-faktor bakat atau kemampuan dasar dalam faktor lingkungan sekitar atau faktor yang disengaja. Pendapat ini dikenal dengan nama hukum Konvergensi. Dengan kata lain, manusia ditentukan perkembanganya oleh faktor dasar dan faktor ajar, yang man asatu sama lain saling mempengaruhi secara interaktif. Jadi pasar, mesjid, dan lembaga pendidikan merupakan faktor yang disengaja dan saling mempengaruhi guna meningkatkan taraf hidup masyarakat sekitarnya.

Keadaan pasar, mesjid dan lembaga sekolah merupakan kondisi yang saling mempengaruhi dan saling membutuhkan. Secara umum permasalahan seperti di atas mungin saja terjadi dimana-mana dalam skala wilayah kota Sorong Papua Barat, dimana muslim merupakan masyarakat minoritas. Maka penting adanya satu penelitian yang mengungkapkan bagaimana hubungan mesjid, lembaga sekolah, dan pasar dalam meningkatkan pendidikan di masyarakat.

\section{Tinjauan Pustaka}

Buku yang memiliki kaitan dengan penelitian ini, karya Mujayyin Arifin dengan yang membahas tentang bagian pandangan tentang proses kependidikan. Mengingat proses kependidikan adalah suatu proses pengembangan kemampuan dasar atau bakat manusia maka dengan sendirinya proses tersebut akan berjalan sesuai dengan hukum-hukum erkembangan, salah satunta hukum konvergensi.

Selain bitu juga kami penulis mengunakan buku karya Hasbullah yang menyatakan bahwa masyarakat begitu berperan dalam pendidikan yang mana masyarakat ikut mendirikan sekolah serta membiayai sekolah, masyarakat juga berperar dalam mengawasi pendidikan agar sekolah tetap membantu dan mendukung cita-cita dan kebutuhan masyarakat, masyarakat sebagia sumber sekolah, mereka dapat diundang ke sekolah untuk memberikan keterangan-keterangan mengenai suatu masalah yang sedang di pelajari anak didiknya di sekolah. 


\section{Metode Penelitian}

Penelitian ini mengunakan metode Observasi dan wawancara yang dilakukan pada tanggal 15 Desember 2012. Wawancara tersebut dilakukan dengan Kepala sekolah SMP Quba Drs Haimun, Wali murid SMP Quba hari dan tanggal yang sama. Selain mengunakan metode wawancara dengan lembaga pendidikan tersebut penulis juga sempat melakukan observasi pada lingkungan sekolah, pasar, dan lingkungan yang berada di sekitar sekolah tersebut tidak ketinggal juga dengan mengobservasi mesjib yang menjadikan awal sekolah tersebut di bangun.

\section{Landasan Teori}

Masyarakat dapat diartikan sebagai suatu bentuk tata kehidupan social dengan tata nilai dan tata budaya sendiri. Dalam arti ini masyarakat adalah wada dan wahana pendidikan, medan kehidupan manusia yang menjemuk (plural, suku, agama, kegiatan kerja, tingkat pendidikan, tingkat social ekonomi dll). Manusia berada dalam maltikomleks antara hubungan dan antaraksi di dalam masyarakat (Barnadib, 1986: 133).

Masyarakat diartikan sebagai kumpulan orang yang menempati suatu daerah yang diikat oleh pengalaman-pengalaman yang sama, memiliki sejumlah persesuaian dan sadar akan kesatuannya, serta dapat bertindak barsama untuk mencukupi krisis kehidupannya (Bahrun, 2009: 102).

Pendidikan selalu diarahkan untuk pengembangan nilai-nilai kehidupan manusia. Di dalam pengembangan nilai ini terseirat pengertian manfaat yang ingin dicapai oleh manusia di dalam kehidupan. Jadi apa yang ingin dikembangkan merupakan apa yang ingin didapatdan dimanfaatkan dari arah pengembangan itu sendiri (Syuaib, 2015: 30).

Sekolah dan masyarakat terdapat hubungan yang erat dan saling mempengaruhi antara satu sama lainya. Dimana tidak dapat dipungkiri bahwa tingkat kecerdasan masyarakat sedikit banyak dapat dikembangkan melalui barbagai program pendidikan di sekolah. Sehingga peran yang dimainkan oleh lembaga persekolahan terutama jalur pendidikan sekolah di dalam meningkatkan intelegensi atau kecerdasan anak didiknya, 
secara langsung bisa dipandang sebagai kontribusi lembaga pendidikan sekolah dalam mencerdaskan kehidupan masyarakat dan bangsa.

Selain itu juga dalam upaya meningkatkan kualitas hidup masyarakat sangat diperlukan adanya pengetahuan baru, teknologi baru, dan pemikiran-pemikiran inovatif yang bersifat fungsional. Sehingga apa yang diharapkan dalam sebuah lembaga pendidikan dapat menjamin upaya agar dapat meningkatkan kecerdasan, dan mengupayakan transformasi dari pengetahuan, pemikiran, dan praktik-praktik baru.dengan inilah masyarakat mendapatkan bekal-bekal pengetahuan yang bisa menjadikan masyarakat yang berkualitas yang siap dan terbekali bagi kepentingan kerja yang akan dilakukan dilingkungan masyarakat tersebut.

Dengan bekal-bekal yang dimiliki masyarakat dapat memunculkan sikap yang positif dan kontruktif sehingga tercipta integrasi sosial yang harmonis di tengah-tengah masyarakat hubungan inilah yang terikat kuat dalam masyarakat dan lenbaga pendidikan meskipun sekolah mempunyai adil yang besar terhadap masyarakat, sebaliknya juga masyarakat juga menuntut agar sekolah mampu memerankan dirinya sejalan dengan keinginan masyarakat tersebut (Hasbullah, 2008: 104-108).

\section{Fungsi dan Peran Pasar}

Pasar adalah tempat bertemunya penjual dan pembeli. Dalam ilmu ekonomi pengertian pasar lebih dititik beretkan pada kegiatan jual belinya. Pasar dapat terbentuk dimana saja dan kapan saja. Syarat-syarat terbentuknya pasar adalah:

1. Adanya penjual.

2. Adanya pembeli.

3. Adanya barang atau jasa yang diperjual belikan.

4. Adanya kesepakatan antara penjual dan pembeli.

\section{Pasar memiliki beberapafungsi diantaranya}

1. Fungsi distribusi

Dalam kegiatan distribusi pasar berfungsi mendekatkan jarak antara konsumen dengan produsen dalam malaksanakan transaksi. Dalam fungsi distribusi pasar 
berperan memperlancar penyaluran barang dan jasa dari produsen kepada konsumen (Ninik, 2015: 50).

2. Fungsi promosi

Pasar merupakan saran apaling tepat untuk ajang promosi, pelaksanaan promosi dapat dilakukan dengan cara memasang spnaduk, menbagikan brosur, menbagikan sampel dan lain-lain.

3. Fungsi pembentukan harga

Pasar berfungsi sebagi pembentukan harga yaitu kesepakatan harga antara penjual dan pembeli.

Selain fungsi pasar juga memiliki beberapa peranan diantaranya sebagai berikut:

a. Peranan pasar bagi produsen sebagai tempat untuk mempromasikan barangbarang sebagai tempat untuk memperoleh bagan produsen.

b. Peran pasar bagi konsumen yaitu memudahkan konsumen untuk mendapatkan barang kebutuhan sebagai tempat bagi konsumen untuk menawarkan sumber daya yang dimiliki.

c. Peran pasar bagi pemerintah adalah sebagi penunjang kelancaran pembangunan dan juga sebagi sumber pendapatan Negara.

\section{Bentuk bentuk pasar antara lain sebagai berikut:}

1. Pasar menurut pelayanan dan perlengkapannya

a. Pasar tradisional

Dalam pasar tradional, pembeli dilayani langsung oleh penjual sehingga di mungkinkan masih terjadi tawar menawar harga.

b. Pasar modern

Dalam pasar modern, pelayanan dilakukan secara mandiri dan dilayani oleh pramuniaga.

2. Pasar menurut Fisik

a. Pasar kongkret adalah pasar dimana penjual dan pembeli bertemu langsung dan barang yang diperjualbelikan benar-benar ada. Ciri-cirinya transaksi tunai, 
barang dapat langsnung dibawa. Barang yang diperjualbelikan benar-benar adadan penjual dan pembeli bertemu langsung.

b. Pasar abstrakadalah pasar dimana penjual dan pembeli tidak bertemu secara langsung. Ciri-cirinya taransaksi berlandaskana rasa percaya, penjual pembeli barada ditampat yang berbeda. Barang yang diperjualbelikan tidak tersedia hanya berupah sebuah contoh saja.

3. Pasar menurut waktu terjadinya

a. Pasar harian, pasar yang menyelenggarakannya setiap hari.

b. Pasar mingguan, pasar yang penyelenggaraannya setiap seminggu sekali.

c. Pasar bulanan, pasar yang penyelenggaraannya sebulan sekali.

d. Pasar tahunan, pasar yang penyelenggaraannya setahuan sekali.

4. Pasar menurut luas wilayah kegiatanaya

a. Pasar lokal, pasar yang daerah pemasarannya meliputi daerah tertentu, barang ang diperjualbelikan adalah barang yang di butuhkan masyrakat di sekitarnya.

b. Pasar nasinal adalah pasar yang daerah pemasarannya meliputi wilayah satu nagara. Barang yang diperjual belikan adalah barang yang dibetuhkan masyarakat Negara tersebut.

c. Pasar regional adalah pasar yang daerah pemasarannya meliputi babarapa Negara diwilayah tertentu dan biasanya di dukung dengan perjanjian kerjasama.

d. Pasar internasinal atau sering dikenal dengan penyebutan pasar dunia adalah pasar yang daerah pemasarannya melipti seluruh kawasan dunia, barang yang di perjualbelikan adalah barang yang dibutuhkan semua masyarakat dunia.

Berbicara masalah pasar seperti diatas dikota Sorong terdapat sebuah pasar dengan nama pasar Central. Pasar tersebut letaknya berdekatan dengan mesjid Quba, lokasi peniagaan tersebut merupakan pasar tradisional jika dilihat dari pelayanan dan kelengkapannya. Namun jika menurut fisik pasar tersebut merupakan pasar kongkrit, bila dilihat dari ciri-cirinya pasar Central merupakan pasar harian, yang penyelenggaraanya setiap hari. 
Selain pasar Central kita juga berbicara tentang lembaga pendidikan yang berada dekat dengan pasar yaitu SMP Quba yang didirikan sebagai tujuan untuk memenuhi kebutuhan masyarakat yang berada disekitanya yang khususnya warga muslim. Sehingga mereka dapat memasukan anak-anaknya di sekolah tersebut.

Visi dan Misi sekolah tersebut adalah tinggi dalam prestasi terpuji dalam budi pekertidengan indikator terwujudnya pola piker yang kritis dan dinamis, terwujudnya prestasi yang tinggi baik akademik maupun non akademik, terwujudnya keimanan dan ketakwaan kapada Tuhan Yang Maha Esa dan terwujudnya perlaku yang bertanggung jawab dan memjunjung tinggi nilai-nilai agama an budaya. Misinya yakni menyelenggarakan pendidikan yang selektif, adaptif, kreatif, tranformatif, dan infratif, tarhadap perkembangan IPTEK dan dilandasi oleh IMTAK (iman dan takwa).

Asal usul nama Quba diambil dari nama mesjid Quba. Dahulu sekolah Quba ini barada di sekitar mesjid Quba sehingga lebih dikenal dengan nama yang sama dengan nama mesjid tersebut, bahkan setelah sekolah tersebut pindah dari mesjid Quba nama tersebut tetap digunakan. Sebab nama Quba itu bagus dan juga agar dapat mudah diingat oleh masyarat.

SMP Quba letaknya dekat pasar Central yang sangat ramai dan padat. Selain itu juga sekolah tersebut berada dekat bandara Edward Osok. Namun uniknya kegiatan pasar dan bandara yang ramai tidak menggangu kegiatan belajar dan mengajar di sekolah Quba. Keadaan pasar dan suara bising pesawat sudah biasa mereka dapati sehingga hal tersebut terasa biasa-biasa saja, berbeda dengan sekolah yang letaknya di daerah kabupaten yang lebih terbiasa belajar dengan suasana yang tenang.

Sekolah Quba telah banyak memberikan kontribusinya bagi masyarakat sekitar, masyarakatpun banyak yang mempercayakan anak-anak untuk sekolah di SMP Quba tersebut. Dari jumlah siswa yng mencapai empat ratus siswa ini dapat menandakan bahwa partisipasi masyaraka sangatlah besar meskipun harus bersaing dengan sekolah-sekolah yang berada di sekitar pasar tersebut. Sekolah Quba selalu berusaha untuk meningkatkan prestasi yang dimilikinya sehingga anak-anak pendidikannya bukan hanya mendapatkan 
ilmu agama saja tetapi mendapatkan pelajaran yang lainnya seperti keterampilanketerampilan yang selalu di berikan kepada anak didiknya.

Siswa dan siswi SMP Quba mayoritasnya dari masyarakat muslim di sekitar lingkungan sekolah tersebut. Sebagian juga siswa lulusan dari SD Quba dan sebagian lagi berasal dari sekolah-sekolah dasar yang lainnya yang berada di daerah Papua Barat. Nama SMP Quba dipilih dengan harapan bahwa masyarakat non muslim pun bisa memasukan anak-anaknya ke sekolah tersebut. Bukan menggunakan MTS Quba, namun sejauh ini tidak ada warga non muslim yang masuk sekolah tersebut. Karena nama Quba sendiri diambil dari nama Mesjid sehingga masyarakat beranggapan bahwa sekolah tersebut khususnya hanya buat kaum muslim saja.

Fasilitas SMP Quba telah memadai dengan jumlah ruang kelas yang kondusif dan mendukung terlihat dari beberapa prestasi yang telah diraih oleh sekolah tersebut. Dari lahir sampai mati manusia hidup sebagai anggota masyarakat. Hidup dalam masyarakat berate adanya interaksi sosial dengan orang-orang di sekitar dan dengan demikian mengalami pengaruh dan mempengaruhi orang lain. Interaksi sosial sangat untama dalam tiang masyarakat. Manusia adalah makhluk sosial. Ia hidup dalam hubunnya dengan orang lain dan hidup bergantung pada orang lain karena itu manusia tak mungkin hidup layak diluar masyarakat.

Kelakuan manusia pada hakikatnya hampir seluruhnya bersifat sosial, yakni dipelajari dalam interaksi dengan manusia lainnya. Hampir segala sesuatu yang kita pelajari merupakan hasil hubungan kita dengan orang lain di rumah, sekolah, tempat bermain, pekerjaan, dan sebagiannya bahan pelajaran atau isi pendidikan ditentukan oleh kelompok atau masyarakat seseorang.

Demikian pula kelompok atau masyarakat menjamin kelangsungan hidup melalui pendidikan. Agar masyarakat itu dapat melanjutkan eksistensinya, maka kepala anggota mudahnya harus diteruskan nilai-nilai, pengetahuan, keterampilan dan bentuk kelakuan lainya yang diharapkan akan dimiliki setiap anggota. Tiap masyarakat meneruskan kebudayaannya dengan beberapa perubahan kepada generasi muda melalui pendidikan, melalui interaksi sosial. Dalam masyarakat yang maju kebanyakan kebiasaan dan pola 
kelakuan yang pokok dalam kebudayaan dipelajari melalui proses pendidikan atau sosialisasi informal. Bahasa, kebiasaan makan, dan kepribadian fundamental sebagian diperoleh melalui pendidikn tak formal.

Dengan demikian, bila lembaga pendidikan dimaksud mampu melahirkan produkproduknya yang berkualitas, tentu saja hal ini merupakan investansi bagi yang penyediaan SDM. Investansi ini sangat penting untuk mengembangkan dan kemajuan masyarakat sebab manusia itu sendiri adalah subjek setiap perkembangan, perubahan, dan kemajuan di dalam masyarakat. Dengan demikian tidak dapat dipungkiri bahwa kecerdasan masyarakat sedikit banyak dapat dikembangkan melalui berbagai program pendidikan disekolah.

Peran yang dimainkan oleh lembaga sekolahan terutama jalur pendidikan sekolah di dalam peningkatan intelegensi kecerdasan anak didiknya, secara langsung bisa dipandang sebagai kontribusi lembaga pendidikan sekolah dalam mencerdaskan kehidupan masyarakat dan bangsa. Bagaimanapun akhirnya anak didik setelah keluar dari lembaga pendidikan akan kembali dan menjadi warga masyarakat.

Pada dasarnya masyarakat senantiasa memiliki dinamika untuk selalu tumbuh dan berkembang, selian tiu juga setiap masyarakat memiliki identitas sendiri sesuai dengan pengalaman dan budaya dan perbendaharaan alamiahnya. Masyarakat dengan segala dinamikanya senantiasa membahwa pengaruh terhadap orientasi dan tujuan pendidikan pada lembaga yang dilahirkan oleh dan untuk masyarakat. Dengan bukti bahwa identitas suatu masyarakat berpengaruh terhadap program pendidikan di sekolah-sekolah adalah dengan berbedanya orientasi dan tujuan pendidikan karakterisrik tersendiri di dalam orientasi dan tujuan pendidikan.

Dalan hal ini begitu besar peranan dari segala aspeknya, yang mana memerlukan kerjasama ataupun usaha bersama. Anak itu sebagai makhluk suatu kebulatan dalam pendidikannya. Ia dipengaruhi oleh lingkungan secara keseluruhan, rumah, sekolah, dan lingkungan yang ada di sekitarnya. Kondisi rumah dikuasai oleh orang tua, sekolah diawasi oleh guru, akan tetapi lingkungan di luar rumah dan sekolah adalah tanggung jawab seluruh masyarakat. 
Kerja sama instansi diperlukan untuk menciptakan lingkungan yang sehat bagi anak-anak.kurangnya perhatian akan apa disebut lingkungan ketiga ini antara lain menyebabkan banyak anak-anak manjadi nakal atau menyimpang kalakuamnya dari norma-norma yang diingnkan masyarakat. Agar masyarakat dapat bertindak diperlukan adanya kepemimpinan. Yang memegang pimpinan tidak selalu mencarinya dari golongan resmi, walaupun bantuan resmi selalu diperlakukan. Dalam masyarakat banyak tersembunyi pemimpin yang dapat di bangkitkan bila diberi kesempatan.

Dalam usaha bersama yang diinginkan adalah pemimpin yang dapat melibatkan setiap peserta agar turut membneri sumbangan pikiran daya dan bila diperlukan. Pemimpin serupa itu menberi dorongan kepada setiap orang untuk mengemukakan pikiran masingmasing secara bebas. Ia menerima dan menghargai segala pendapat, juga yang bertentangna dan kemudian berusaha mencapai suatu kebulatan keputusan yang didasarkan atas segala simbangan pikiran yang konstruktif.

Penyelenggaraan pendidikan di sekolah melibatkan berbagai komponen, baik yang memanusiawi maupun nonmanusiawi, dan dalam hal ini ada partisipasi masyarakat jelas berpengaruh terhadap penyelengaraan pendidikan. Sehingga dalam fungsi proses penyelenggaraan pendidikan di sekolah-sekolah tergantung pada ualitas dan kuantitas komponen ma nusiawi, fasilitas, dana, dan perlengkapan pendidikan.

Pendidikan merupakan sebuah kebutuhan yang sangat penting yang harus kita penuhi sehingga kita dapat mengetahua apa yang tidak kita ketahui. Pendidikan dapat dilakukan disekolah. Karena sekolah-sekolah telah memiliki fungsi yaitu sebagai berikut:

a. Sekolah mempersiapkan anak untuk suatu pekerjaan

Anak yang telah menamatkan sekolah diharapkan sanggup melakukan pekerjaan sebagai mata pencariannya atau setidaknya mempunyai dasar untuk mencari nafkah. Makin tinggi pendidikan makin besar harapan syarat mpekerjaan yang baik. Ijazah masih tetap dijadikan syarat penting untuk suatu jabatan, walaupun ijazah itu sendiri belum menjamin kesiapan seseorang untuk melakukan pekerjaan tertenti. Akan tetapi dengan ijazah yang tinggi seseorang dapat meahami dan menguasai pekerjaan kepemimpinan atau tugas lainny. Kerena dengan memiliki ijazah perguruan tinggi 
merupakan bukti akan kesanggupan intelektualnya untuk menyelesaikan studinya yang tidak mungkin dicapai oleh orang yang rendah kemampuannya. Sekolah yang ditempuh seseorang banyak menentukan pekerjaan yang dilakukan oleh seseorang.

b. Sekolah memberikan keterampilan dasar

Orang yang telah bersekolah setidaknya pandai membaca, menulis, dan berhitung, yang diperlukan dalam tiap masyarakat modern. Selain itu diperoleh sejumlah sengetahuan lain seperti sejarah, biografi, geugrafi, fisika, bahasa, dan lain-lain yang menbekali anak untuk melanjutkan pelajarannya atau memperluas pandangan dan pemahaman tentang masalah-masalah dunia.

c. Sekolah membuka kesempatan memperbaiki nasib

Sekolah sering dipandang sebagi jalan mobilitas sosial. Melalui pendidikan orang dari golongan rendah dapat meningkatkan ke golongan yang lebih tinggi. Orang tua mengharapkan agar anak-anaknya mempunyai nasib yang lebih baik oleh karena itu orang tua berusaha untuk menyekolahkan anaknya jika mungkin sampai memperoleh gelas dari suatu perguruan tinggi, walaupun sering dengan pengorbanan yang besar menyenai pembiayaannya.

d. Sekolah menyediakan tenaga pembangunan

Bagi Negara-neraga berkembang, pendidikan dipandang sebangai alat yang paling ampuh untuk menyiapkan tenaga yang terampil dan ahli dalam segala sector pembangunan. Kekayaan alam hanya mengandung arti bila didukung oleh keahlian. Maka karena itu manusi merupakan sumber utama bagi pembagunan nagara.

e. Sekolah membantu memecahkan masalah-masalah sosial

Masalah-maslah sosial diharapkan dapat diatasi dengan mendidik generasi muda untuk mengelakkan atau mencegah penyakitsosial seperti kejahatan, pertumbuhan penduduk yang melewati batas kecelakaan lalu lintas, narkoba dan sebagiannya.

f. Sekolah mentransmisi kebudayaan

Demi kelangsungan hidup bangsa dan Negara, kepala generasi muda disampaikan nilai-nilai yanh dijunjung tinggi oleh bangsa itu. Setiap warganegara diharapkan menghormati pahlawannya, menjunjung tinggi nilai-nilai lihur yang 
diwariskan nenek moyang dan dengan demikian meresapkan sara kesatuan dan persatuan bangsa.

g. Sekolah menbentuk manusia yang sosial

Pendidikan diharapkan membentuk manusia sosial, yang dapat bergaul dengan sesame manusia sekalipun berbeda agama, suku, bangsa, pendirian, dan sebagian. Ia harus dapat menyesuaikan diri dalam situasi sosial yang berbeda-beda.

h. Sekolah merupakan alat mentransformasi kebudayaan

Sekolah terutama perguruan tinggi diharapkan menambah pengetahuan dengan mengadakan penemuan-penemuan baru tang dapat membawaperubahan dalam masyarakat. Perkembangan ilmu pengetahuan dan teknologi telah membahwa perubahan yang besardi dunia ini. Ada tokoh pendidikan yang beraggapan bahwa sekolah dapat diguakan untuk menrekonstruksi masyarakat bahkan dapat mengontrol perubahan-perubahan itu dengan cara sosial engineering.

Oleh kerana itu pasar merupakan salah satu bentuk kehidupan sosial masyarakat dalam mempertahankan hidupnya. Aktifitas pasar merupakan salah satu contoh bahwa manusia saling membutuhkan. Selian manusia menpunyai hubungan yang baik antara sesamanya manusia juga harus mempnyai hubungan yang baik dengan sang pencipta. Hal tersebut wajib adanya Allahlah yang menciptakan dunis dan seisinya patut kita sembah sebagai rasa syukur kita kepadaNya. Rasa syukur itu kita realisasikan dengan ibadah dalam kehidupan sehari-hari baik ketika berniaga ibadah ini penting, khususnya bagi seorang muslim ada kewajiban shalat lima waktu sehari.

Mesjib merupakan tempat ibadah bagi kaum muslim. Tempat untuk mengumandangkan adzan, mengingatkan masyarakat yang berada di pasar kepada waktu shalat. Keberadaan mesjid Quba di sekitar pasar Central memiliki peranan yang sangat penting bagi orang-orang yang sedang berniaga di pasar. Pasar dan mesjid tidak dapat dipisahkan keduanya saling membutuhkan dan saling menguntungkan antara satu dengan yang lainnya.

Mesjid memiliki fungsi dan peran yang dominan dalam kehidupan masyarakat umat Islam beberapa diantaranya adalah sebagai berukut 
1. Sebagai tempat ibadah.

Sesuai dengan namanya mesjid adalah tempat sujud, maka fungsi utamanya adalah sebagai tempat ibadah shalat. Sebagaimana diketahui bahwa makna ibadah di dalam Islam adalah luas menyangkut segala aktifitas kehidupan yang di tujukan untuk memperoleh ridha Alla Swt. maka fungsi mesjid di samping sebagai tempat shalat juga sebagai tempat beribadah secara luas sesuai dengan ajaran Islam.

2. Sebagai tempat menuntut ilmu

Mesjid berfungsi sebagai tempat untuk bekajar mengajar. Khususnya ilmu agama yang merupakan kewajiban bagi setiap umat Islam untuk mempelajarinya. Disamping itu juga ilmu-ilmu lain, baik ilmu alam, sosial, humaniora, keterampilan dan lain-lain sebagaimana dapat diajarkan di mesjid.

3. Sebagai tempat pembinaan jamaah

Dengan adanya umat Islam disekitarnya mesjid berperan dalam koordinir mereka guna menyatukan potensi dan kepemimpinan umat. Selanjutnya umatyang terkoordinir secara rapi dalam organisasi Tamir mesjid dibina keimanan, ketakwaan, ukhuwah imaniah dan dakwa Islamiyah. Sehingga mesjid dapat digunakan sebagia basis umat Islam yang mana bisa meningkatkan keimanan bagi setiap umat muslim dan menjadikan mereka sebagi pejuang-pejuang yang kokoh.

4. Sebagai pusat dakwa dan kebudayaan Islam

Mesjid merupakan jantung kehidupan umat Islam yang selalu berdenyut untuk menyebarluaskan dakwa Islamiyah dan budaya Islam. Di mesjid pula direncanakan, diorganisasi, dikaji, dilaksanakan dan dikembangkan dakwa dan kebudayaan Islam yang menyahiti kebutuhan masyarakat. Kerena itu mesjid berperan sebagai sentra aktif dakwa dan kebudayaan.

5. Sebagai pusat kaderisasi umat

Sebagai tempat pembinaan jamaah dan kepemimpinan umat mesjid memerlukan aktivis yang berjuang menegakkan Islam secara istiqamah dan berkesinabungan, patah tumbuh hilang berganti. Karena itu pembinaan kader perlu di persiapkan dan 
dipusatkan di mesjid sejak mereka masih kecil sampai dewasa. Diantaranya denan taman pendidikan Alquran (TPA), remaja mesjid maupun Tamir Mesjidbeserta kegiatannya.

6. Sebagai basis kebangkitan umat Islam

Adab sekarang ini telah direncanakan umat Islam sebagai sebagai adab kebangktan Islam. Umat Islam yang sekian lama tertidur dan tertinggal dalam percaturan peradaban dunia berusaha untuk bangkit dengan berdasarkan nilai-nilai aspek, baik idiologi, hukum, ekonomi, politok, budaya, social, dan sebagiannya. Setelah itu dicoba untuk di apliasikan dan dikembangkan dalam kehidupan nyata umat. Menafani kehidupan dunia ini dengan nilai-nilai Islam. Proses Islamisasi dalam segala aspek kehidupan secara arif dan bijaksana.

Umat Islam erusaha bangkit.. kebangkitan ini memerlikan peren mesjid sebagai basis perjuangan. Kebangkitantak berawal dari mesjid menuju masyarakat secara luas. Karena itu upaya aktivisasi fungsi dan peran mesjid pada abad sekarang ini adalah sangat mendesak yang dilkukan umat Islam.

Dengan melihat dari fungsi sekolah yang telah dijelaskan di atas, maka SMP Quba yang berada disekitar pasar dan mesjid merupakan uatu kesatuan realitas kehidupan yang mampu menjadikan masyarakaynya menjadi masyarakat madani.

Masyarakat Madani adalah masyarakat yang beradab, menjunjung tinggi nilai-nilai kemanusiaan, serta masyarakat yang maju dalam penguasaan ilmu pengetahuan, dan teknologi. Masyaakat madani itu sebenarnya merujuk pada masyarakat Islam yang pernah dibangun nabi Muhammad di negeri Madinah. Perkataan Madinah dalam bahasa arab dapat dipahami dari dua sudut pengertian. Pertama, secara konvensional kata madinah dapat bermakna sebagai "kota", dan kedua, secara kebahasaan dapat berarti "peradaban"; meskipun di luar ata "madaniyah" tersebut, apa yang disebut peradaban juga berpadanan dengan kata "tamaddun"dan"hadlarah".

Sebelumnya, apa yang dikenal sebagai kota madinah itu adalah daerah yang bernama Yatsrib. Nabi-lah yang kemudian mengubah namanya menjadi Madinah, setelah hijrah ke kota itu. Perubahan nama Yatsrib menjadi Madinah pada hakikatnya adalah 
sebuah proklamasi untuk mendirikan dan membangun masyarakat berperadaban di kota itu. Dasar-dasar masyarakat madani inilah, yang tertuang dalam sebuah dokumen "Piagam Madinah" yang didalamnya menyangkut antara lain wawasan kebebasan, terutama di bidang agama dan ekonomi, tanggung jawab social dan politik, serta pertahanan, secara bersama. Di kota Madinah-lah, Nabi membangun masyarakat berperadaban berlandaskan ajaran Islam, masyarakat yang bertaqwa kepada Ketuhanan Yang Maha Esa. Semangat ketaqwaan yang dalam dimensi vertikal untuk menjamin hidup manusia, agar tidak jatuh hina dan nista.

Ciri-ciri Masyarakat Madani

1. Menjunjung tinggi nilai, norma, dan hukum yang ditopang oleh iman dan teknologi.

2. Mempunyai peradaban yang tinggi (beradab)

3. Mengedepankan kesederajatan dan transparasi ( keterbukaan)

4. Free public sphere (ruang publik yang bebas)

Ruang publik yang diartikan sebagai wilayah dimana masyarakat sebagai warga negara memiliki akses penuh terhadap setiap kegiatan publik, warga negara berhak melakukan kegiatan secara merdeka dalam menyampaikan pendapat, berserikat, berkumpul serta mempublikasikan pendapat, berserikat, berkumpul serta mempublikasikan informasi kepada publik.

5. Demokratisasi

Menurut Neera Candoke, masyarakat sosial berkaitan dengan wacana kritik rasional masyarakat yang secara ekspisit mensyaratkan tumbuhnya demokrasi, dalam kerangka ini hanya negara demokratis yang mampu menjamin masyarakat madani. Demokratisasi dapat terwujud melalui penegakkan pilar-pilar demokrasi yang meliputi: 1) Lembaga Swadaya Masyarakat (LSM) 2) Pers yang bebas 3) Supremasi hokum 4) Perguruan Tinggi 5) Partai politik

6. Toleransi

Toleransi adalah kesediaan individu untuk menerima pandangan-pandangan politik dan sikap sosial yang berbeda. Toleransi merupakan sikap yang dikembangkan dalam masyarakat madani untuk menunjukan sikap saling 
menghargai dan menghormati pendapat serta aktivitas yang dilakukan oleh orang atau kelompok masyarakat yang lain yang berbeda.

7. Pluralisme

Pluralisme adalah sikap mengakui dan menerima kenyataan disertai sikap tulus bahwa masyarakat itu majemuk. Kemajemukan itu bernilai positif dan merupakan rahmat tuhan.

8. Keadilan Sosial (social justice)

Keadilan yang dimaksud adalah keseimbangan dan pembagian yang proporsional antara hak dan kewajiban setiap warga dan negara yang mencakup seluruh aspek kehidupan.

9. Partisipasi sosial

Partisipasi sosial yang benar-benar bersih dari rekayasa merupakan awal yang baik bagi terciptanya masyarakat madani. Partisipasi sosial yang bersih dapat terjadi apabila tersedia iklim yang memunkinkan otonomi individu terjaga.

10. Supermasi hukum

Penghargaan terhadap supermasi hukum merupakan jaminan terciptanya keadilan, keadilan harus diposisikan secara netral, artinya tidak ada pengecualian untuk memperoleh kebenaran di atas hukum.

Cita-cita Islam merupakan refleksi tauhid yang merupakan prinsip sentral dan kardinal dalam Islam. Tauhid menekankan kasatuan hubungan tiga eksistensi: tuhan, alam dan manusia, manusia sebagai sebyek kehihudan merupakam khaliah Tuhan yang diberi kuasa untuk memanfaatkan alam untuk membangun peradaban di bumi. Keberhasilan misi kekhalifahan tersebut sangat tergantung kepada kemampuan manusia dalam mengembangkan sunnahtullah dalam dirinya,yakni dengan menginternalisasikan kekuatankekuatan Tuhan sehingga manusia dapat memahami dan memanfaatkan sunnahtullah pada alam semesta. Pengembangan misi khilafah ini meniscayahkan kerja kolektif manusia dengan manusia yang lainya. Konsep kekhalifahan manusia dengan demikian mengandung dimensi sosial baik pada proses maupun tujuannya. 
Orang tua mempunyai peranan pertama dan utama bagi anak-anaknya selam anak belum dewasa dan mampu berdiri sendiri. Untuk membawa anak kepada kedewasan, orang tua harus member teladan yang baik karena anak suka mengimitasi kapada orang yang lebih tua atau orang tuanya. Dengan teladan yang baik , anak anak memiliki sifat yang baik pula sehingga dalam pergaulan dia dapat memiliki siapa saja yang menjadi temantemannya. Karena dalam hidup barmasyarakat kita tidak dapat hidup sendirian, kita membutuhkan orang lain dalam kehidupan kita sehari-hari.

Mesjid, pasar dan sekolah memiliki nilai-nilai pendidikan yang berbeda. Sehingga begitu baiknya setiap lingkunagn yang ada di sekitar kita menjadi tempat yang baik untuk dijadikan tempat untuk diambil nilai-nilai baiknya.sehingga kita dapat menjadikan ilmu yang kita miliki sebagia contoh yang baik buar semua orang.

\section{Kesimpulan}

Masyarakat adalah sekelompok manusia yang terjalin erat karena sistem tertentu, tradisi tertentu, konvensi dan hukum tertentu yang sama dan hidup bersama. Hidup bersama tidak berarti sekelompok orang mestihidup berdampingan di satu daerah tertentu, memanfaatkan iklim ang sama, dan mengkonsumsikan makanan yang sama

Pasar adalah tempat bertemunya penjual dan pembeli. Dalam ilmu ekonomi pengertian pasar lebih dititik beretkan pada kegiatan jual belinya. Karena ditempat inilah terjadinya transaksi antara penjual dan pembeli yang akan saling menukar antara barang dan uang.

Dikota Sorong terdapat sebuah pasar dengan nama pasar Central. Pasar tersebut letaknya berdekatan dengan mesjid Quba lokasi peniagaan tersebut merupakan pasar tradisional jika dilihat dari pelayanan dan kelengkapannya. Namun jika menurut fisik pasar tersebut merupakan pasar kongkrit, bila dilihat dari ciri-cirinya pasar Central merupakan pasar harian, yang penyelenggaraanya setiap hari.

Seliain berbicara soal pasar, terdapat lembaga pendidikan yang barada di dekat lingkungan pasar tersebut dan sekolah ini telah berdiri cukup lama. Walaupun letaknya berdampingan dengan pasar yang dikenal dengan keramainya setiap hati ini tidak 
menggurangi ataupun menggangu aktifitas belajar mengajar yang terjadi pada lembaga pendidikan tersebut. Lembaga pendidikan ini di kenal dengan nama SMP Quba.

Visi dan Misi sekolah tersebut adalah tinggi dalam prestasi terpuji dalam budi pekertidengan indikator terwujudnya pola piker yang kritis dan dinamis, terwujudnya prestasi yang tinggi baik akademik maupun non akademik, terwujudnya keimanan dan ketakwaan kapada Tuhan Yang Maha Esa dan terwujudnya perlaku yang bertanggung jawab dan memjunjung tinggi nilai-nilai agama an budaya. Misinya yakni menyelenggarakan pendidikan yang selektif, adaptif,kreatif, tranformatif, dan infratif, tarhadap perkembangan IPTEK dan dilandasi oleh IMTAK (iman dan takwa).

Fasilitas SMP Quba telah memadai dengan jumlah ruang kelas yang kondusif dan mendukung terlihat dari beberapa prestasi yang telah diraih oleh sekolah tersebut.dari lahir sampai mati manusia hidup sebagai anggota masyarakat. Hidup dalam masyarakat berate adanya interaksi sosial dengan orang-orang di sekitar dan dengan demikian mengalami pengaruh dan mempengaruhi orang lain. Interaksi sosial sangat untama dalam tiang masyarakat. Manusia adalah makhluk sosial. Ia hidup dalam hubunnya dengan orang lain dan hidup bergantung pada orang lain karena itu manusia tak mungkin hidup layak diluar masyarakat.

Mesjid merupakan tempat ibadah bagi kum muslim. Tempat untuk mengumandangkan adzan, mengingatkan masyarakat yang berada di pasar kepada waktu shalat. Keberadaan mesjid Quba di sekitar pasar Central memiliki peranan yang sangat penting bagi orang-orang yang sedang berniaga di pasar. Pasar dan mesjid tidak dapat dipisahkan keduanya saling membutuhkan dan saling menguntungkan antara satu dengan yang lainnya.

Dengan melihat dari fungsi sekolah yang telah dijelaskan di atas, maka SMP Quba yang berada disekitar pasar dan mesjid merupakan uatu kesatuan realitas kehidupan yang mampu menjadikan masyarakaynya menjadi masyarakat madani.

Ciri-ciri Masyarakat Madani

1. Menjunjung tinggi nilai, norma, dan hukum yang ditopang oleh iman dan teknologi.

2. Mempunyai peradaban yang tinggi (beradab). 
3. Mengedepankan kesederajatan dan transparasi (keterbukaan).

4. Free public sphere (ruang publik yang bebas)

\section{Daftar Pustaka}

Bahrun. Dasar-Dasar Pendidikan dalam Islam, Cet. I; Pali: Yayasan Masyarakat Indonesia Baru, 2009.

Barnadib, Sutari Imam. Pengantar Ilmu Pendidikan Sistematis, Yogyakarta: FIP-IKIP, 1986.

Hasbullah. Dasar-Dasar Ilmu Pendidikan (Edisi Revisi), Jakarta: PT Raja Grafindo Persada, 2009.

Mallaombasi, Syuaib. "Pendidikan anak dan Aspek Sosial dalam Tuntunan Agama." Jurnal Auladuna, Vol. 2 No. 1, Juni 2015.

Murtadha, Muthahhari. Manusia dan Alm Semesta, Cet. II; Jakarta: Lentera, 2002.

Muzayyin, Arifin. Filsafat Pendidikan Islam, Cet. II; Bandunga: PT. Bmi Aksara, 2001.

Nasution. Sosiologi Pendidikan, Cet. VI; Jakarta: Bumi Aksara, 2011.

Rustanti, Ninik. Ekonomi Pangan dan Gizi, Cet. I; Yogyakarta: Deepublish, 2015.

Syam, Mohammad Noor. Filsafat Pendidikan dan Dasar Filsafat Pancasila, Surabaya: Usaha Nasional 1986.

Syamsudin, Din. Etika Agama Dalam Menbangun Masyarakat Madani, Cet. I; Jakarta: Logos, 2000. 